\title{
MANAJEMEN PENDIDIKAN DALAM PERSPEKTIF AL-QUR'AN
}

\author{
Hasan Zaini \\ Program Studi Pendidikan Agama Islam, J unusan Tarbiyah STAIN Batusangkar \\ J. Sudiman No.137 Kubu Rajo, Lima Kaum Batusangkar \\ e-mail: profhasanzaini@yahoo.com
}

\begin{abstract}
Management of education in perspective al-Qur'an. The Qur'an is the way of life of all time, which is relevant in every time, place and situation. In the Qur'an not only discussed the matter of belief, worship, morals, halal and haram, but there are also issues of science. Among them about education issues, including the scope of Management Education. Word "Yudabbiru " which means set, can be used as the basis that the Qur'an there memamng discuss management ( setting) of God to his creation, including arranging all the affairs of His creatures. This can be understood from the fact that man as a vicegerent of God on earth has the duty and obligation to manage, administer and prosperity of this earth. Education includes administering and managing well education Management is the foundation of Islam Qur'an and Hadith with the principle of Tauhid, Khalifah and trustful. Furthermore, the function of which is popularly called management Planning, Organizing, Actuating and Controlling, in line with the teachings of the Qur'an, that in life and life, man must have the planning, organization, unity and mutual cooperation. In addition it should also be able to move others to do good in the form of motivation, advice and guidance. Then needs to be controlled and monitored in order to get maximum results.
\end{abstract}

Kata kunci: Al-Qur'an, perspektif, manajemen pendidikan.

\section{PENDAHULUAN}

Dalam rangka mewujudkan bangsa yang berbudaya tinggi, tak ada alasan untuk mengabaikan pengelolaan lembaga pendidikan di abad ke-21 ini. Dengan kata lain pendidikan sebagai satu kegiatan fundamental manusia benar-benar memerlukan upaya pengelolaan terencana, terarah, terorganisir dan terpadu. Hal itu penting dilakukan karena pendidikan merupakan kegiatan yang berorientasi masa depan (future oriented) dan menyangkut pembinaan potensi masyarakat baik secara pribadi maupun masyarakat dan bangsa yang berlangsung sepanjang hayat.

Keberhasilan pendidikan bukan hanya ditentukan oleh materi ajar, metode, sarana, prasarana, media dan perlengkapan lainnya, tapi juga ditentukan oleh manajemen dan organisasi pengelolaannya dalam hal ini 
termasuk pendidikan Islam. Melalui tulisan ini penulis akan mencoba mengungkap bagaimana pandangan Al-Qur'an tentang manajemen pendidikan dengan pendekatan Tafsir Maudhu'i (tematik) yaitu memilih suatu tema tertentu untuk dibahas, kemudian menghimpun ayat-ayat Al-Qur'an yang berkaitan dengan tema tersebut.

\section{PEMBAHASAN}

\section{Seputar Al-Qur'an}

Al-Qur'an menurut bahasa (etimologi) adalah bentuk mashdar dari: qaraa, yaqrau, qur'an, qiraat, yang berarti bacaan. Bentuk Fi'il Amar nya adalah: Iqra' (bacalah). Al-Qur'an menurut istilah (terminologi) adalah Kalam Allah yang tiada tandingannya (mu'jizat), diturunkan kepada Nabi Muhammad SAW, penutup para Nabi dan Rasul dengan perantaraan malaikat Jibril AS, ditulis dalam mushhaf yang disampaikan kepada kita secara mutawatir (oleh orang banyak) serta mempelajarinya merupakan suatu ibadah, dimulai dengan surat AlFatihah dan ditutup dengan surat $\mathrm{Al}-\mathrm{Naas}$ (Muhammad Aly Ash-Shabuny, 1987;18).

Berbeda dengan kitab-kitab suci sebelumnya, seperti Taurat, Injil, dan Zabur yang diturunkan sekaligus, AlQur'an diturunkan secara berangsur-angsur (Tanjiman) selama 22 tahun, 2 bulan, 22 hari. Hal ini dimaksudkan agar Nabi dan para sahabat lebih mudah menghafalnya serta sesuai dengan situasi dan kondisi ketika ayat itu diturunkan, yang melatarbelakangi turunnya (Asbabun Nuzul).

Al-Qur'an memperkenalkan dirinya sebagai al-kitab (kitab, buku) yang tidak mengandung keraguan sedikitpun, hudan (petunjuk) bagi orang-orang bertakwa pada khususnya (Q.S: 2;2) dan bagi umat manusia pada umumnya, al-Furqan (pembeda antara yang baik dan yang buruk).(Q.S: 2;185). Al-Qur'an juga sebagai rahmat, syifa' (obat penawar khususnya untuk hati yang resah dan gelisah), mau'izhah (nasehat atau wejangan) (QS. Yunus, 10;57 dan Bani Israil, 17;82) dan sebagainya. Nama-nama tersebut memberikan indikasi bahwa alqur'an adalah kitab suci yang berdimensi banyak dan berwawasan luas.

Isi kandungan Al-Qur'an mencakup masalah akidah dan kepercayaan, syari'at (hukum), ibadah, akhlak, kisah-kisah wa'ad, wa'id, ekonomi, sains termasuk fisika, biologi, kimia,dll), pendidikan, pengajaran, dakwah dan komunikasi serta seterusnya. Khusus tentang pendidikan dan pengajaran termaktub dalam ayat dan surat yang pertama kali diturunkan kepada Nabi Muhammad SAW, yaitu surat al-Alaq $1-5$ yang mengandung perintah membaca (iqra) yang diulang dua kali dalam surat ini. Hal ini menunjukkan betapa pentingnya membaca untuk mendapatkan ilmu pengetahuan. Tidak disebutkannya objek baca (maf'ul bih) dalam ayat ini suatu isyarat bahwa yang dibaca itu bukan saja yang tersurat (maktub) tapi juga yang tersirat (ghairu maktub). 
Dengan kata lain baik ayat-ayat quraniyah ataupun ayat kauniyah (berkaitan dengan alam)

\section{Pengertian Persfektif}

Perspektif berasal dari bahasa Belanda, berarti (1) sesuatu yang harus diperhatikan dalam membuat gambar; dan (2) pandangan jauh kemasa depan (J.S. Badudu, Sutan Muhammad Zain, 1994: 1048 - 1049). Menurut Peter Salim, Perspektif dapat berarti (1) cara melukiskan sesuatu benda dan lain-lain pada permukaan yang mendatar sebagaimana yang terlihat oleh mata dengan tiga dimensi (panjang, lebar dan tingginya); dan (2) sudut pandangan, pandangan (Depertemen Pendidikan dan Kebudayaan), 1989: 675; lihat juga Peter Salim, Yenny Salim, 1991: 1146). Jadi yang dimaksud dengan judul tulisan ini adalah : bagaimana pendangan Al-Qur'an tentang Manajemen Pendidikan atau dengan kata lain, bagaimana Manajemen Pendidikan menurut Pandangan Al-Qur'an.

\section{Pengertian Manajemen}

Secara etimologis, kata "manajemen" berasal dari kata "managio", berarti pengurusan atau "managiare" yaitu melatih dalam mengatur langkah-langkah, atau dapat berarti bahwa manajemen sebagai ilmu, kiat dan profesi (Sagala, 2004: 13). Kata "manajemen" juga berasal dari bahasa Inggris yakni berasal dari kata kerja (verb) "to manage" yang identik dengan kata "to control" dan "to handle"(Hornby, 1987: 517). Jadi kata manajemen secara etimologis berarti mengelola, memeriksa atau mengawasai dan mengurus.

Secara terminologis kata "manajemen" memiliki banyak makna. antara lain:

a. Nanang Fattah dalam bukunya Landasan Manajemen Pendidikan mengatakan: "manajemen merupakan proses merencana, mengorganisir, memimpin dan mengendalikan upaya organisasi dengan segala aspeknya agar tujuan organisasi tercapai secara efektif dan efisien".(Fattah, 2004:1). Definisi ini dapat diambil pemahaman bahwa ada beberapa kata kunci (keyword) dalam manajemen yaitu perencanaan (planning), mengorganisasi (organizing), memimpin (guiding), mengendalikan(controlling) dan pencapaian tujuan (the achievement of the goal). Dari beberapa kata kunci tersebut dapat dikonstruksi sebuah pemahaman bahwa yang dimaksud dengan manajemen adalah suatu proses perencanaan, pengorganisasian, pelaksanaan dan pengendalian atau pengawasan dari sumber daya organisasi untuk mencapai tujuan secara efektif dan efisien.

b. George B. Terry dalam Manullang memberikan pengertian istilah manajemen sebagai berikut: management is distinct process, consisting of planning, organizing, actuating, controlling, utilizing 
in each both science and art and follow in order to accomplish pride termined objectives (Manullang, 1987:45).

Definisi Terry menjelaskan bahwa manajemen adalah sebuah proses yang khas, terdiri dari tindakantindakan perencanaan (planning), pengorganisasian (organizing), pergerakan (actuating), dan pengawasan (controlling). Bidang-bidang manajemen tersebut masing-masing memiliki ilmu keahlian serta seni yang dapat dilaksanakan secara beraturan dalam rangka mencapai sasaran yang telah ditetapkan semula menjadi arah dari semua aktivitas organisasi.

\section{Pendidikan Islam}

Sebelum menjelaskan pengertian pendidikan Islam, terlebih dahulu penulis menjelaskan pengertian pendidikan menurut Kamus Bahasa Indonesia; Pendidikan berasal dari kata "didik". Kata ini mendapat awalan kata "me" sehingga menjadi "mendidik" artinya memelihara dan memberi latihan. Dalam memelihara dan memberi latihan diperlukan adanya ajaran, tuntunan dan pimpinan mengenai akhlak dan kecerdasan pikiran (Desi Anwar, 2002: 232).

Menurut Bahasa Yunani, Pendidikan berasal dari kata "pedagogi" yaitu kata "paid"artinya membimbing, sehingga "pedagogi" dapat diartikan sebagai "ilmu dan seni mengajar anak". Sedang pengertian pendidikan Islam ada beberapa istilah yang digunakan untuk itu, yaitu al-Tarbiyyat, al-Ta'lim, al-ta'dib.(Ramayulis, 2011: 14). Ada pula yang menambahkan kata alTadris untuk pendidikan. Kata lain yang seakar dengan Al-Tarbiyyat adalah al-Rabb, rabbayani, murabbiy, Yurbiy, dan Rabbany. Masing-masing kata tersebut sebenarnya memiliki kesamaan makna walaupun dalam konteks tertentu memiliki perbedaan. Al-Tarbiyyah memiliki arti memperbaiki, menguasai urusan, memelihara, merawat, menunaikan, tumbuh dan berkembang.

Pengertian ini antara lain dapat dilihat dalam surat al-Rum ayat 39:

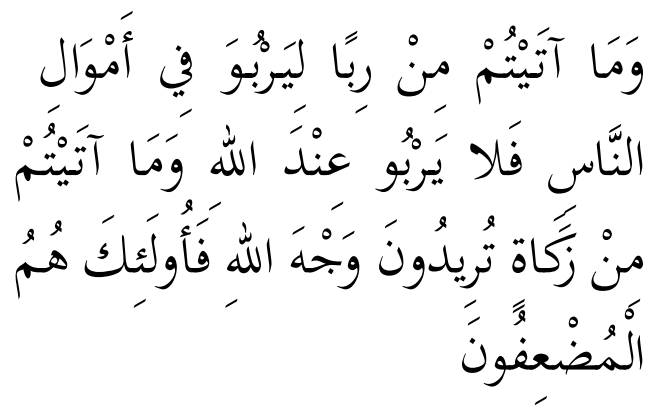

Dan sesuatu riba (tambahan) yang kamu berikan agar dia bertambah pada harta manusia, maka riba itu tidak menambah pada sisi Allah. Dan apa yang kamu berikan berupa zakat yang kamu maksudkan untuk mencapai keridaan Allah, maka (yang berbuat demikian) itulah orang-orang yang melipat gandakan (pahalanya)"(QS 30:39).

Istilah lain dari pendidikan adalah Ta'lim, merupakan mashdar dari kata 'allama yang berarti mengajarkan atau pengajaran yang bersifat pemberian atau penyampaian pengertian, pengetahuan dan keterampilan. Penunjukkan kata Ta’lim pada pengertian 
pendidikan, sesuai dengan dirman Allah dalam surat Al-Baqarah ayat 31:

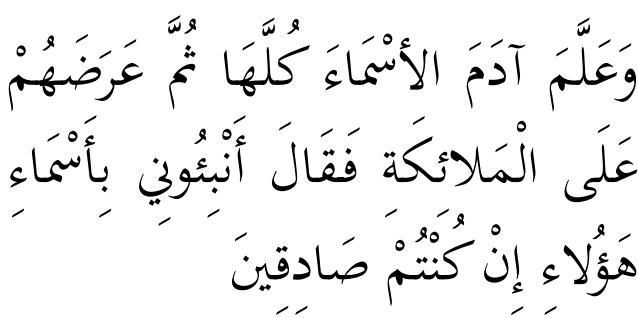

Dan Dia mengajarkan kepada Adam nama-nama (benda-benda) selurubnya, kemudian mengemukakannya kepada para malaikat, lalu berfirman"sebutkanlah kepada-Ku nama benda-benda itu jika Kamu memang orang-orang yang benar"(QS. 2:31.)

Berdasarkan ayat di atas dari kata ta'lim terlihat pengertian pendidikan terlalu sempit, yaitu sebatas proses penuturan seperangkat nilai antar manusia. Ia hanya dituntut untuk menguasai nilai-nilai yang ditransfer secara kognitif dan psikomotorik, akan tetapi tidak dituntut pada domain Afektif (Samsul Nizar, 1999:47). Jadi kata Ta'lim hanya sebatas transfer ilmu.

Selanjutnya istilah al-Tádib mengandung pengertian mendidik, melatih, memperbaiki, mendisiplinkan, memberi tindakan untuk berperilaku lebih baik. (Samsul Nizar, 1999: 48). Kata Tádib ditemui dalam hadis Nabi antara lain:

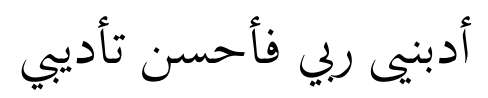

"Tuhanku telah mendidikku. Lalu mendidikku secara baik".

Kemudian ada juga yang memasukkan kata Tadris kedalam makna pendidikan sehingga pendidik selain disebut murabbi, mua'ddib, mu'allim juga disebut madarris dan tempat belajar disebut madrasah (sekolah). Pada masa sekarang ini istilah yang paling popular dipakai orang adalah "Tarbiyyah" karena menurut Athiyah al-Abrasyi, sebagaimana dikutip oleh Ramayulis, tema yang mencakup keseluruhan pendidikan adalah tarbiyyah karena merupakan upaya yang mempersiapkan individu untuk kehidupan yang lebih sempurna dan sistematis dalam berfikir, memiliki ketajaman intuisi, giat dalam berkreasi, memiliki toleransi pada yang lain, berkompetensi dalam mengungkapkan bahasa lisan dan tulisan serta memiliki beberapa keterampilan (Ramayulis, 2011:16).

\section{Manajemen Pendidikan Islam Persfektif Al-Qur'an}

Terminologi Islami yang secara khusus menyebutkan istilah manajemen belum ada yang popular. Namun bila didekati dari istilah bahasa Arab dapat dikemukakan di sini bahwa kata "Yudabbiru" dapat diartikan mengarahkan, mengelola, melaksanakan, menjalankan, mengatur atau mengurusi. Asal katanya adalah dari "dabbara" yang artinya mengaturkan dan mudabbir artinya "orang yang pandai mengatur " atau pengatur “mudabbar" yang "diatur " (Yunus, 1973: 110).

Bertitik tolak dari pengertian manajemen seperti telah disebutkan sebelumnya dan dikaitkan dengan pengertian "tadbir" 
yang bermakna mengatur, maka dapat disimpulkan bahwa manajemen pendidikan islam adalah suatu proses mulai dari perencanaan, pengorganisasian, pelaksanaan dan pengawasan yang didasari oleh nilainilai Islam.

Setidaknya kata "Yudabbiru" muncul dalam empat ayat yang secara umum menggambarkan bahwa Allah SWT yang mengatur segala urusan. Keberadaan Allah sebagai Maha Pencipta dihubungkan dengan penciptaan alam, langit dan bumi serta segala isinya sehingga segala urusan yang ada di alam semesta ini adalah Allah yang Maha Mengetahui, mengawasi dan memeliharanya. Bahkan menurut Mahdi (1986) dalam al-Qur'an ada lebih dari 750 ayat yang menunjuk kepada fenomena alam dan manusia diminta untuk dapat memikirkannya agar dapat mengenal Tuhan lewat tanda-tandanya.

Berikut ini dicantumkan ayat-ayat yang berhubungan dengan "Tadbir" atau manajemen tersebut:

1. Surat Yunus, ayat 3:

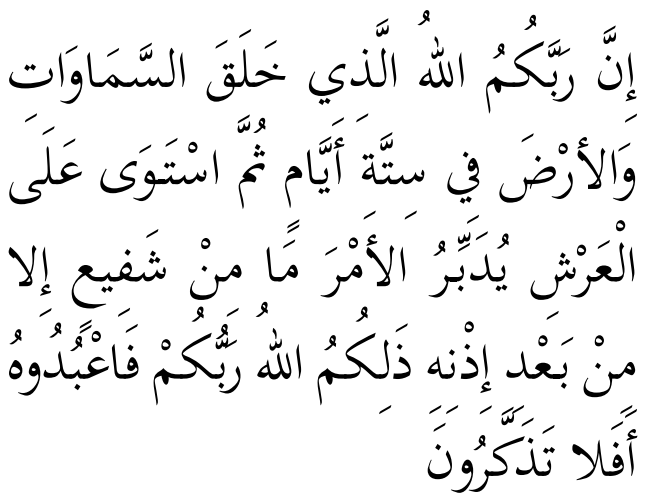

Sesungguhnya Tuhan kamu ialah Allah yang menciptakan langit dan bumi dalam enam masa. Kemudian bersemayam di atas Arasy (singgasana) untuk mengatur segala urusan. Tiada seorangpun yang akan memberi syafaat kecuali sesudah ada keizinanNya. Yang demikian itulah Allah, maka sembahlah Dia. Maka apakah kamu tidak mengambilpelajaran "? (QS. 10:3)

Jadi pengaturan urusan yang ada di alam ini benar-benar berdimensi "Tauhid" atau mengakar pada tindakan pengesaan Allah.

\section{Surat Yunus ayat 31:}

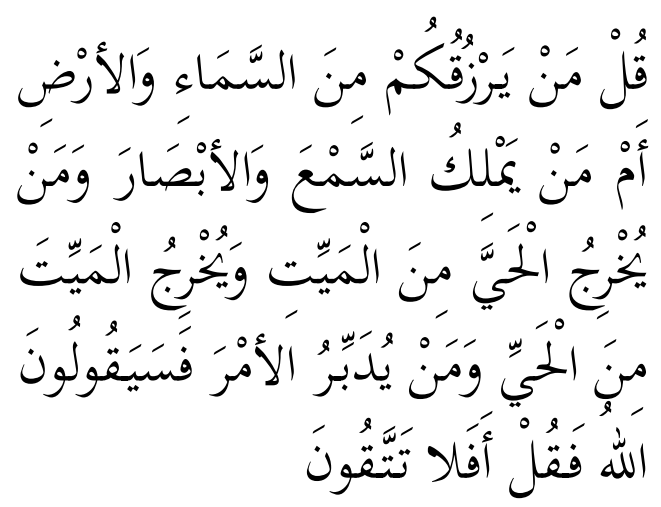

"Katakanlah, siapakah yang memberi rezki kepadamu dari langit dan bumi, atau siapakan yang kuasa (menciptakan) pendengaran dan penglihatanmu, siapakah yang mengeluarkan yang hidup dari yang mati dan mengeluarkan yang mati dari yang hidup dan siapakan yang mengatur segala urusan? Maka mereka akan menjawab "Allah", maka katakanlah "Mengapa kamu tidak bertaqwa kepada Allah?”(QS. 10:31)

Jadi alam raya ini benar-benar Allah yang mengatur dan mengendalikannya, termasuk pengaturan rezki manusia bahkan mengatur 
segala urusan. Anehnya, manusia mengakui semuanya itu, namun masih ada yang tidak bertaqwa. Surat-surat lainnya yang memberi petunjuk yang sama antara lain surat Al- Ra'du:2, al-Sajadah:5,dsb. Sebagai Maha Pencipta, Allah yang mengatur segala urusan makhluk-Nya di bumi ini. Dengan Qudrat, Iradat dan Ilmu-Nya .Allah SWT memberi kemampuan potensial bagi manusia untuk menjadi wakil Tuhan atau Khalifatullah dan pemimpin di muka bumi ini, setelah manusia menerima amanat dari Allah dan makhluk lain (malaikat, bumi dan gunung-gunung) menolak untuk mengelola bumi. Oleh sebab itu, management Islami diletakkan pada prinsip Tauhid bahwa Allah sebagai Maha Pencipta dan Pengatur (Mudabbir) dengan segala urusan makhlukNya dan konsep khalifah yang diberikan kepada status manusia di muka bumi dengan konsekwensi bertanggung jawab mengelola, memelihara dan mengawasi kelangsungan hidup di alam ini.

Sebagaimana kita ketahui bahwa Al-Qur'an bukanlah buku teks sains experimental. Pernyataan Al-Qur'an tentang fenomena alam paling tidak memiliki beberapa alasan mengikut pendapat Ghulsyani (1986) yaitu:

1. Studi fenomena alam dan keajaibankeajaiban penciptaan alam memperkuat keimananan manusia kepada Tuhan.

2. Dengan keakraban terhadap kesempatankesempatan yang diberikan Tuhan kepada manusia, ia lebih dapat mengenal
Allah dan dengan mendapatkan manfaat darinya, ia dapat bersyukur kepadaNya. Dari sini muncul pengakuan akan kebanaran pengetahuan yang utama tentang ke-Esa-an Allah ( Tauhid).

\section{Prinsip Manajemen Pendidikan Islami}

Ilmu manajemen telah berkembang sebagai fenomena kehidupan modern menyertai kehadiran berbagai organisasi di masyarakat. Di dalamnya dimaksudkan untuk pengelolaan kegiatan manusia dalam memenuhi kebutuhan hidupnya secara bersama. Perilaku bekerjasama sebagai sesuatu yang bersifat fitrah dilaksanakan pada prinsip tauhid, khalifah dan amanah Prinsip manajemen Islam adalah:

\section{a. Tauhid}

Tauhid menempatkan manusia pada kehidupan tertentu sejak dari etika niat se bagai awal dari pemenuhan tuntutan dalam ketika tindakan. Apapun usaha dan tindakan manusia harus sesuai dengan kehendak Allah SWT dengan keikhlasan dan ketauhidan. Setiap tindakan dan usaha $m$ anusia apalagi yang terkait dengan ibadah madhoh (yang ditentukan) tidak boleh bertentangan dengan ke-Esa-an Allah (QS. 39:3; 2:112; 26:89; 50:37). Al Faruqi (1980:16) menjelaskan bahwa "The Principle of taubid or The Unization of God, the recognition of Him as one, absolute and transcendent, is also at the centre of the muslims Couriosity regarding nature". Dengan kata 
lain, prinsip tauhid harus menjadi fundasi bagi seluruh perilaku individu dan kelompok dalam membangun kebudayaannya.

\section{b. Khalifah (Pemimpin/manajer)}

Allah SWT menciptakan manusia sebagai makhluk terbaik ciptaan-Nya (QS. 95:4; 51:56) berarti keta'atan dan kepatuhan manusia kepada Allah merupakan alasan penciptaan manusia. Karena itu kekhalifahan manusia di bumi juga merupakan tujuan penciptaan manusia (QS.2:30; 6:165), dan sekaligus hanya manusia yang mau dan mampu menerima amanah dari Allah dengan etika religius bahwa manusia bebas memilih dan berkehendak untuk mengikuti perintah-perintah Allah.

Tujuan manusia sebagai pemimpin dan manajer di bumi ini ialah memakmurkan alam sebagai manifestasi dari rasa syukur manusia kepada Allah dan pengabdian kepada-Nya. Tugas khalifah diberikan kepada setiap manusia, maka dalam pelaksanaannya terkandung sikap kebersamaan atau pertanggungjawaban bersama kepada Allah akan kemakmuran alam ini. Konsep ini melahirkan nilai yang sangat penting tentang "pemimpin" kepemimpinan dan anggota atau yang dipimpinnya serta situasi dimana kepemimpinan itu berlingsung.

Dalam surat Al-Anbiya' ayat 73:

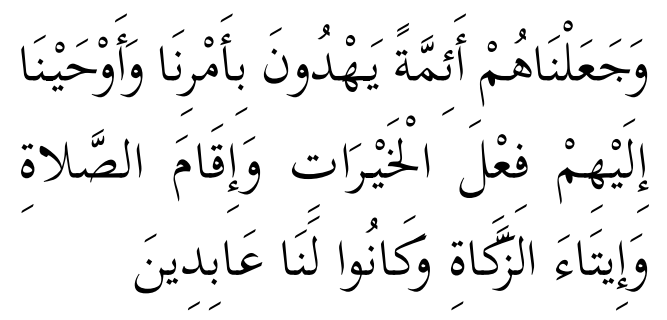

0 Jurnal al-Fikrah, Vol. I, No. 1, Januari-Juni 2013
Kami telah menjadikan mereka itu sebagai pemimpin-pemimpin yang memberi petunjuk dengan perintah Kami dan telah Kami wahyukan kepada mereka, mendirikan sholat, menunaikan zakat dan hanya kepada Kami mereka selalu menyembah" (QS.21:73).

Bagi setiap umat ada pemimpin yang dipercayai (credible) sehingga mereka dapat mengajarkan tentang kebenaran, kebijakan dan kemuliaan dengan keteladanannya. Pemimpin harus menjadi penolong, penggerak, mengarahkan dan membimbing anggota organisasi untuk memenuhi kehendak Allah. sebagaimana firman Allah dalam surat Al-Taubah : 71 dan Al-Baqarah :44 :

Seorang pemimpin harus menjadi panutan dan contoh teladan bagi orang yang dipimpinnya, dan harus sejalan antara ucapan dan perbuatan.

\section{c. Amanah}

Setiap manajer adalah pemimpin. Karena itu Allah telah mempercayakan manusia mengelola alam ini untuk kebaikan manusia dan kemakmuran alam, berarti keteladanan manusia yang menduduki jabatan tertentu sangat diperlukan untuk kebaikan organisasi dan masyarakat.

Diantara ayat Al-Qur'an yang berhubungan dengan amanah dan kejujuran antara lain, Surat Al-Baqarah :283

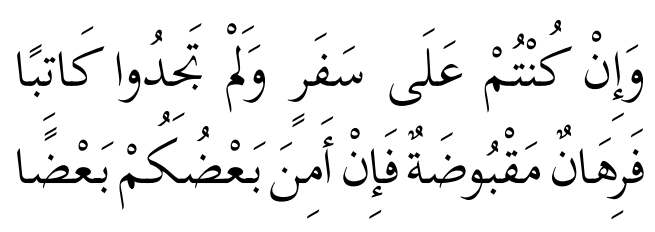




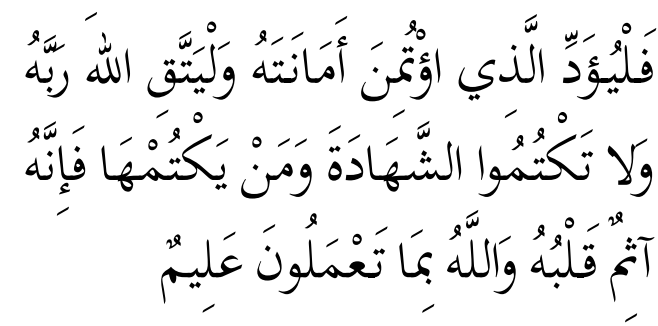

Jika kamu dalam perjalanan (dan bermuamalah tidak secara tunai) sedang kamu tidak memperoleh seorang penulis, maka hendaklah ada barang tanggungan yang dipegang (oleh yang berpiutang). Akan tetapi jika sebagian kamu mempercayai sebagian yang lain, maka hendaklah yang dipercayai itu menunaikan amanatnya (utangnya) dan hendaklah ia bertakwa kepada Allah Tuhannya; dan janganlah kamu (para saksi) menyembunyikan persaksian. Dan barang siapa yang menyembunyikannya, maka sesungguhnya ia adalah orang yang berdosa hatinya; dan Allah Maha mengetahui apa yang kamu kerjakan." (QS. 2: 283).

Hal yang sama juga dijelaskan dalam surat An-Nisak:58 dan al-Taubah:119 serta surat $A l-M a^{\prime} i d a h$ ayat $119 ; A l$ An'am:40,143;Yusuf:17, 27, 51.

Di samping tiga prinsip dasar (tauhid, khalifah dan amanah) tersebut, manajemen pendidikan Islam juga sejalan dengan prinsip dan langkah-langkah manajemen modern yang dikenal dengan istilah Planning, Organizing, Actuating dan Controling (POAC).

\section{a. Perencanaan (Planning).}

Setiap orang pasti ingin hidup bahagia, sejahtera, aman, dan makmur bukan hanya di dunia bahkan juga di akhirat. Seperti firman Allah dalam surat Al-Baqarah ayat 201:

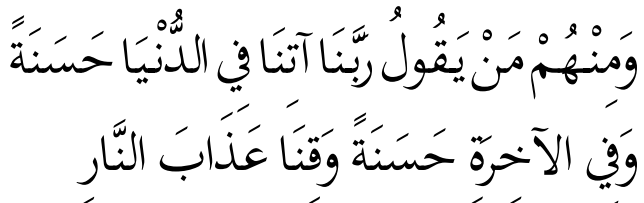

Dan di antara mereka ada orang yang berdoa: "Ya Tuhan kami, berilah kami kebaikan di dunia dan kebaikan di akhirat dan peliharalah kami dari siksa neraka". (QS. 2:201)

dan juga dalam surat $A l-Q$ ashash ayat 77:

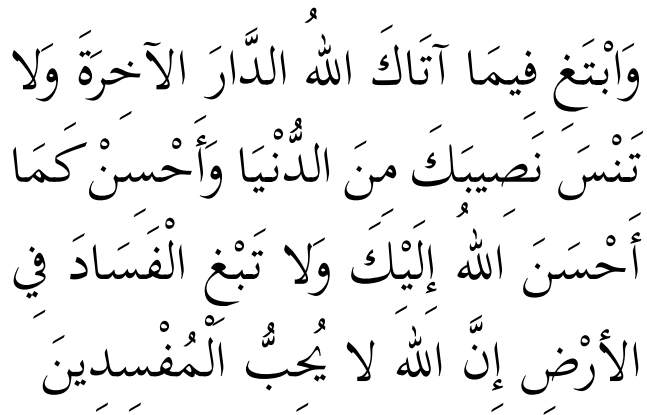

Dan carilah pada apa yang telah dianugerahkan Allah kepadamu (kebahagiaan) negeri akhirat, dan janganlah kamu melupakan bahagianmu dari (kenikmatan) duniawi dan berbuat baiklah (kepada orang lain) sebagaimana Allah telah berbuat baik kepadamu, dan janganlah kamu berbuat kerusakan di (muka) bumi. Sesungguhnya Allah tidak menyukai orang-orang yang berbuat kerusakan."(QS. 28: 77).

Dalam surat Al-Baqarah ayat 201 Allah menyatakan bahwa di antara manusia berdoa kepada Allah untuk mendapatkan kebahagiaan dunia dan akhirat serta terlepas dari siksa neraka. Dalam surat Al-Qashash ayat 77 Allah menyuruh manusia mencari kebahagiaan akhirat melalui nikmat pemberian Allah kepada mereka. Namun tidak melupakan kebahagiaan di dunia. Kedua 
ayat tersebut mengandung pengertian bahwa manusia harus hidup dalam keseimbangan antara kepentingan dunia dan akhirat, atau dengan kata lain dunyawi dan ukhrawi, fisik material dan mental spiritual, yang biasa disebut pembangunan manusia seutuhnya.

Untuk mencapai kebahagiaan dan kesuksesan hidup, diperlukan program dan perencanaan yang matang. Seperti ditegaskan dalam Firman Allah surat $\mathrm{Al}$ Hasyr ayat 18:

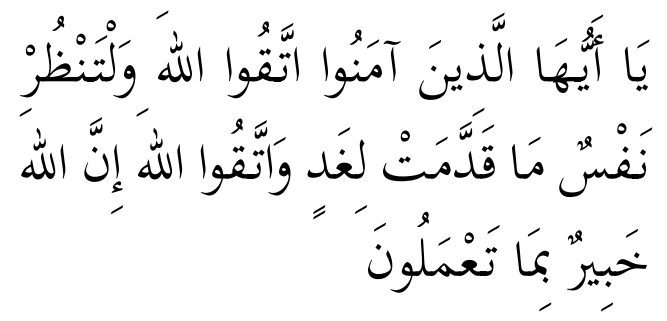

Hai orang-orang yang beriman, bertakwalah kepada Allah dan hendaklah setiap diri memperhatikan apa yang telah diperbuatnya untuk hari esok (akhirat), dan bertakwalah kepada Allah, sesungguhnya Allah Maha Mengetahui apa yang kamu kerjakan." (QS. 59: 18).

Dalam ayat ini dinyatakan bahwa setiap individu harus menyiapkan bekal untuk menghadapi masa depan atau hari esok, sehingga hari esok lebih baik dari hari ini, dan hari ini lebih baik dari hari kemarin. Kerena itu harus dibuat program dan perencanaan yang matang. Bila telah selesai satu program, kerjakan program yang lain, seperti ditegaskan oleh Allah dalam surat Al-Insyirah ayat 5-8:

Dalam Al-Qur'an, diungkapkan kisah Nabi Yusuf AS. Yang membuat rencana makro berjangka panjang tentang persiapan atau perencanaan pangan. Yusuf AS. Memerintahkan supaya bertani dan bercocok tanam selama tujuh tahun untuk menghadapi tahun sulit atau kemarau panjang yang akan terjadi tujuh tahun yang akan datang. Ini dapat dibaca dalam surat Yusuf ayat 47-49

\section{b. Pengorganisasian (organizing)}

Pengorganisasian dalam pendidikan islam adalah proses pemantauan struktur, aktivitas, interaksi, koordinasi, desain struktur, wewenang tugas secara transparan dan jelas dalam lembaga pendidikan islam, baik yang bersifat individual, kelompok, maupun kelembagaan.

Sehubungan dengan pengertian istilah ini, Sarwoto mengatakan "pengorganisasian sosial sebagai keseluruhan proses pengelompokkan orang-orang, alat-alat tugas, tanggung jawab atau wewenang sedemikian rupa, sehingga tercipta suatu organisasi yang dapat digerakkan sebagai satu kesatuan dalam rangka mencapai tujuan yang telah ditetapkan" (Sarwoto, 1987:77).

Dengan perumusan seperti di atas, dapat dipahami bahwa pengorganisasian merupakan langkah ke arah pelaksanaan rencana yang telah disusun sebelumnya. Jadi kegiatan pengorganisasian merupakan fungsi organik yang kedua dalam manajemen. Dalam fungsi pengorganisasian terdapat sekelompok orang yang mau bekerja sama, ada tujuan yang hendak dicapai, ada pekerjaan yang akan dikerjakan, ada pembagian tugas 
yang jelas, pengelompokkan kegiatan, menyediakan alat-alat yang dibutuhkan untuk aktivitas organisasi, ada pendelegasian wewenang antara atasan dan bawahan serta pembuatan struktur organisasi yang efektif dan efisien.

Dalam Al-Qur'an, manusia disuruh tolong menolong, bekerjasama dalam mencapai tujuan yang baik, dan dilarang tolong menolong dan bekerjasama atas perbuatan dosa dan permusuhan, seperti Firman-Nya dalam surat Al-Maidah:2 dan Ali Imran :103

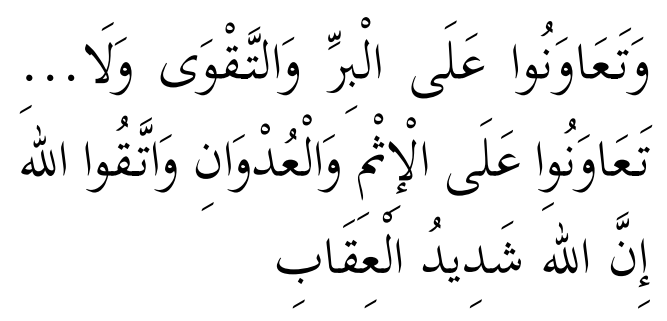

Dan tolong-menolonglah kamu dalam (mengerjakan) kebajikan dan takwa, dan jangan tolong-menolong dalam berbuat dosa dan pelanggaran. Dan bertakwalah kamu kepada Allah, sesungguhnya Allah amat berat siksa-Nya. (QS. 5:2)

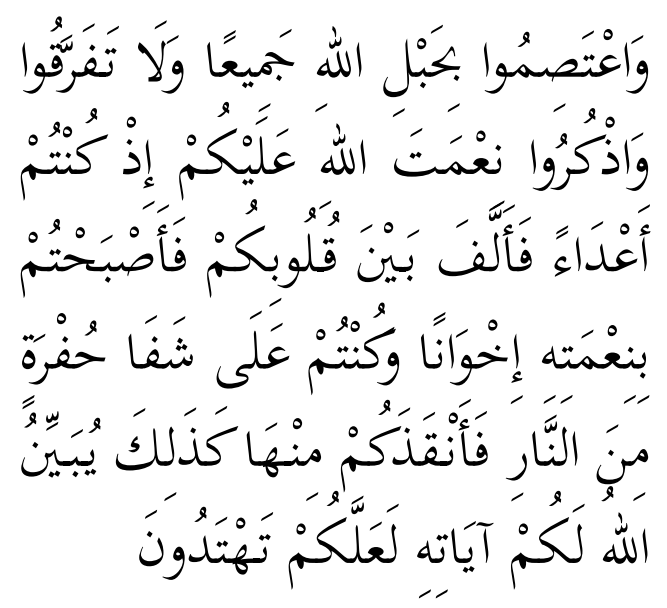

Dan berpeganglah kamu semuanya kepada tali (agama) Allah, dan janganlah kamu bercerai berai, dan ingatlah akan nikmat Allah kepadamu ketika kamu dabulu (masa Jahiliah) bermusuh musuhan, maka Allah mempersatukan hatimu, lalu menjadilah kamu karena nikmat Allah orang-orang yang bersaudara; dan kamu telah berada di tepi jurang neraka, lalu Allah menyelamatkan kamu daripadanya. Demikianlah Allah menerangkan ayatayat-Nya kepadamu, agar kamu mendapat petunjuk. (QS. 3:103)

Dalam sebuah hadis Nabi disebutkan:

$$
\text { الجماعة رحمة والفرقة عذاب }
$$

Persatuan membawa rabmat dan perpecehan membawa azab

Pujangga Arab menyatakan: الاتحاد اساس النجاح, persatuan itu tiang kemenangan.

\section{c. Pergerakan (actuating)}

George R. Terry (dalam Sunarto, 1987:86) mendefinisikan actuating sebagai: "tindakan untuk mengusahakan agar seluruh anggota kelompok suka berusaha untuk mencapai sasaran, agar sesuai dengan perencanaan manajerial dan usaha-usaha organisasi"

Pergerekan (actuating) adalah hubungan antara aspek-aspek individual yang ditimbulkan oleh adanya hubungan terhadap bawahan untuk dapat mengerti dan memahami pembagian pekerjaan yang efektif dan efisien. Actuating adalah bagian yang sangat penting dalam proses manajemen. Berbeda dengan ketiga fungsi yang lain (planing, organizing, controling), actuating 
dianggap sebagai intisari manajemen karena secara khusus berhubungan dengan orangorang. Seorang menejer atau pimpinan termasuk pimpinan dalam bidang pendidikan harus bisa menggerakkan bawahan supaya mau dan rajin belajar sesuai dengan bidang masing-masing, karena itu ia harus pandai memberikan motivasi untuk membangkitkan semangat kerja. Ini sesuai dengan Surat Al-Baqarah ayat 25:

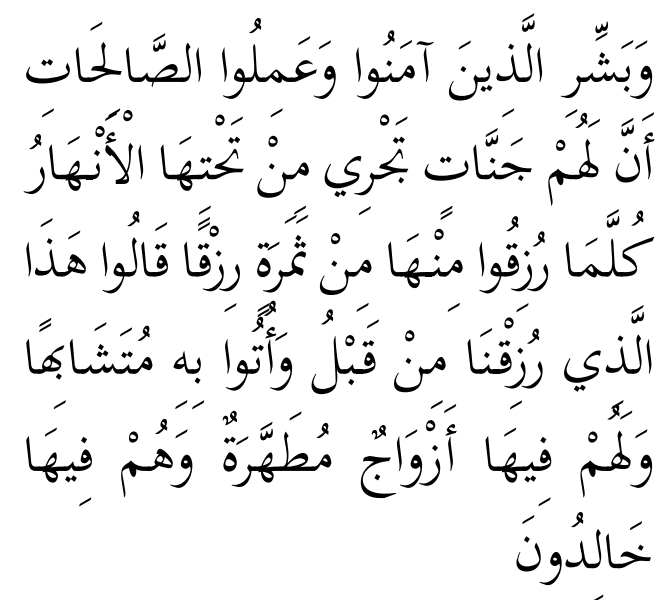

Dan sampaikanlah berita gembira kepada mereka yang beriman dan berbuat baik, bahwa bagi mereka disediakan surgasurga yang mengalir sungai-sungai di dalamnya. Setiap mereka diberi rezeki buah-buahan dalam surga-surga itu, mereka mengatakan: "Inilah yang pernah diberikan kepada kami dahulu. " Mereka diberi buah-buahan yang serupa dan untuk mereka di dalamnya ada istri-istri yang suci dan mereka kekal di dalamnya. (QS. 2:25)

Dalam mengajak bawahan, staf seorang pimpinan harus bersikap sopan santun, lemah lembut dan tidak kasar, sesuai dengan firman Allah dam Surat Ali Imran ayat 159:

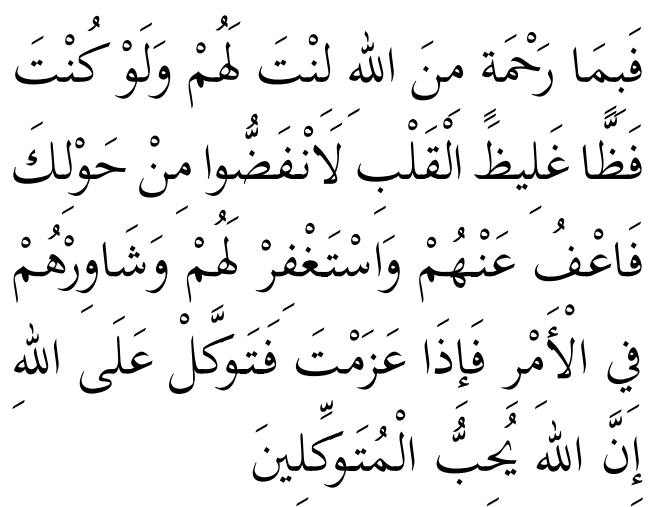

Maka disebabkan rahmat dari Allah-lah kamu berlaku lemah-lembut terhadap mereka. Sekiranya kamu bersikap keras lagi berhati kasar, tentulah mereka menjaubkan diri dari sekelilingmu. Karena itu maafkanlah mereka, mohonkanlah ampun bagi mereka, dan bermusyawarahlah dengan mereka dalam urusan itu. Kemudian apabila kamu telah membulatkan tekad, maka bertawakallah kepada Allah. Sesungguhnya Allah menyukai orang-orang yang bertawakal kepada-Nya. (QS 3:159)

\section{d. Pengawasan (controling)}

Terry (1978) sebagaimana dikutip Khatibul Umam (2003:51) mendefinisikan pengawasan sebagai berikut:

"Controlling can be difined a the proses of determining what is to be accomplish that is the standart, what is being accomplish, that is the performance, evaluating the performance and if necessary applying connective measures so that performance that is in conformity with the standart."

Pengawasan adalah proses penentuan apa yang dicapai berkaitan dengan standar apa yang dihasilkan, penilaian pelaksanaan (performansi) serta bilamana perlu diambil 
tindakan kolektif. Ini yang memungkinkan pelaksanaan dapat berjalan sesuai dengan standar (yang diharapkan).

Sedangkan Sarwoto (1987:93) memberikan batasan pengawasan sebagai "kegiatan manajer yang mengusahakan agar pekerjaan-pekerjaan terlaksana sesuai dengan rencana yang ditetapkan atau haril yang dikehendaki. Ini berarti betapapun baiknya sebuah rencana akan bisa gagal apabila manjer tidak melakukan pengawasan.

Bila dihubungkan dengan pendidikan Islam dapat dipahami bahwa semua perbuatan diawasi dan dikontrol oleh Allah Swt dan Allah selalu melihat dan memperhatikannya. Bahkan gerak gerik dan niat hati manusiapun diketahui oleh Allah. Mengenai ini dapat dibaca dalam surat Ali Imran ayat 29:

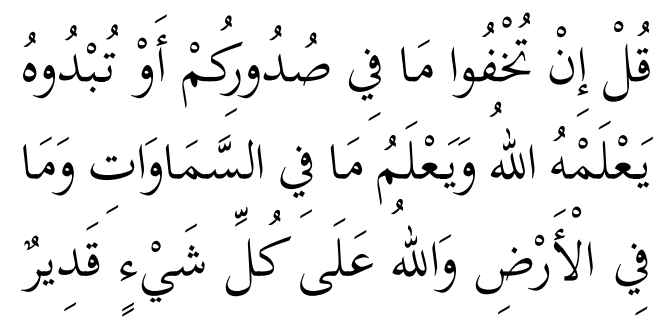

Katakanlah: "Jika kamu menyembunyikan apa yang ada dalam hatimu atau kamu melabirkannya, pasti Allah mengetahui." Allah mengetahui apa-apa yang ada di langit dan apa-apa yang ada di bumi. Dan Allah Maha Kuasa atas segala sesuatu. (QS 3:29)

Dan Surat Hud ayat 5:

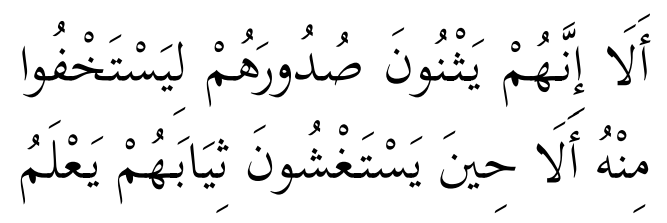

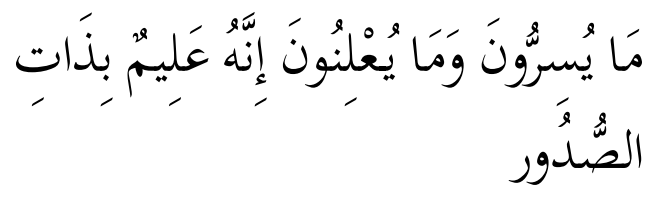

Ingatlah, sesungguhnya (orang munafik itu) memalingkan dada mereka untuk menyembunyikan diri daripadanya (Muhammad). Ingatlah, di waktu mereka menyelimuti dirinya dengan kain, Allah mengetahui apa yang mereka sembunyikan dan apa yang mereka labirkan, sesungguhnya Allah Maha Mengetahui segala isi hati. (QS.11:5)

Selain itu manusia juga dikontrol dan diawasi oleh malaikat Raqib dan Atid atau malaikat Kiraman Katibin yang selalu mencatan dan mengawasi perbuatan manusia, seperti firman-Nya dalam surat Al-Infithar ayat 10-12:

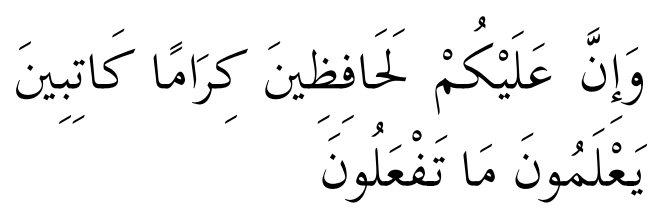

Padahal sesungguhnya bagi kamu ada (malaikat-malaikat) yang mengawasi (pekerjaanmu), yang mulia (di sisi Allah) dan yang mencatat (pekerjaanpekerjaanmu itu), mereka mengetahui apa yang kamu kerjakan. (QS.82:10-12)

Bertitik tolak dari pengawasan atau kontrol Allah terhadap hamba-Nya, maka manusia sebagai khalifah dan pemimpin atau manajer harus pula mengawasi dan mengontrol bawahan, anggota dan anak buahnya tak terkecuali pemimpin dalam bidang pendidikan. Mulai dari Menteri, Kepala Dinas sampai kepada Kabid, Kasi 
bahkan Kepala Sekolah harus mengontrol pelaksanaan pendidikan bahkan oleh pemerintah telah diangkat para pengawas Pendidikan atau pengawas Sekolah, baik pendidikan Agama maupun pendidikan umum.

\section{PENUTUP}

Dari uraian di atas dapat dismpulkan bahwa dalam Al-Qur'an terdapat ayat-ayat yang ada hubungannya dengan manajemen seperti kata "Yudabbiru" yang mengacu kepada pengaturan alam raya oleh Allah SWT, kemudian dapat pula dipahami dalam fungsi manusia sebagai Khalifah (wakil) Allah sebagai pemimpin untuk mengatur dan memakmurkan Alam ciptaan Allah SWT ini.

Begitu juga ditemui ayat-ayat yang berkaitan dengan fungsi dan prinsip manajemen yaitu Planning, Organizing, Actuating, dan controlling. Dalam mengelola pendidikan Islam juga perlu ditempuh langkah-langkah tersebut. Bedanya manajemen pendidikan Islam berlandaskan Al-Qur'an dan Hadis serta analisa (Ijtihad) para ahli dan mufassir yang kompeten di bidangnya.

Keberhasilan pendidikan Islam bukan hanya ditentukan oleh lengkapnya sarana dan prasarana, kurikulum, silabus, media dan sebagainya, tapi juga sangat ditentukan oleh sumberdaya manusia yang melaksanakannya sebagai manajer atau pimpinan.

\section{KEPUSTAKAAN ACUAN}

Al-Abrasyi, M.Athiyah. 1969. Al-Tarbiyah al-Islamiyah wa Falsafatuha. Qahirah: Isa al-Bab Al-Halaby.

Abd al-Baqi, Muhammad Fuad. 1994. AlMujjam Al-Mufahrasy li Alfaz Al-Qur'an Al-Karim. Mesir: Dar al-Fikr.

Al-Maraghi, Ahmad Musthafa. 1974. Tafsir al-Maraghi. Mesir: Mustafa Al-Bab alHalaby.

Ash-Shabuny, Muhammad Aly. 1987. Pengantar Study Al-Qur'an (Al-Tibyan). Terjemahan oleh Muhammad Chaddari Umar, dkk. Bandung: Al-Ma’arif.

Baharuddin dan Moh. Hakim. 2010. Manajemen Pendidikan Islam. Malang: UIN Maliki Press.

Deden Makbulah. 2011. Manajemen Mutu Pendidikan Islam. Jakarta: Raja Grafindo Persada.

Departemen Pendidikan dan Kebudayaan. 1989. Kamus Umum Bahasa Indonesia. Jakarta: Balai Pustaka.

Fattah, Nanang. 2004. Landasan Manajemen Pendidikan . Bandung: Penerbit Remaja Rosdakarya.

Horn by AS. 1987. Oxford Advanced Learner's Dictionary of Current English. London: Oxford University Press.

Ibn Zakaria, Abu Husein Ahmad Ibn Faris 1994. Mujam al-Maqayis fi al-Lughah. Beirut: Dar al-Fikri. 
J.S. Badudu dan Sutan Muhammad Zain. 1994. Kamus Umum Bahasa Indonesia. Jakarta: Pustaka Sinar Harapan.

Manullang. 1987. Manajemen Sumber Daya Manusia. Jilid I. Yogyakarta: Andi Offset.

Muhaimin dkk. 2009. Manajemen Pendidikan. Jakarta: Kencana Prenada Media Grup.

Nata, Abuddin. 2001. Manajemen Pendidikan. Jakarta: Prenada Media.

Pidarta Made. 2004. Manajemen Pendidikan Indonesia. Jakarta: PT. Renika Cipta.

Ramayulis. 2011. Ilmu Pendidikan Islam. Jakarta: Kalam Mulia.

Sagala, Syaiful. 2004. Manajemen Berbasis Sekolah dan Masyarakat. Strategi Menangkan Persaingan Mutu. Jakarta: Nimas Multima.

Salim, Peter dan Yenny Salim. 1991. Kamus Bahasa Indonesia Kontemporer. Jakarta: English Press.
Sarwoto. 1978. Dasar-Dasar Organisasi dan Manajemen. Jakarta: Ghalia Indonesia. Syafyarma. 2003. Manajemen Pendidikan. Bandung: Alfabeta.

Syamsul Nizar, 1999. Peserta Didik Dalam Perspektif Islam. Padang: IAIN Imam Bonjol Press.

Syafaruddin. 2005. Manajemen Lembaga Pendidikan Islam. Ciputat: Ciputat Press.

Tilana, H.A.R.M. 2006. Manajemen Pendidikan Nasional. Bandung: PT. Remaja Rosdakarya Offset.

Yusuf Qardhawi. 1999. Al-Qur'an Berbicara Tentang Akal dan Ilmu Pengetahuan. Jakarta: Gema Insani Press.

Yunus, Mahmud. Sejarah Pendidikan Islam di Indonesia. Jakarta: Mutiara Sumber Widya. 